Natalia Parfeniuk

ORCID: 0000-0002-6411-3069

Uniwersytet Narodowy Akademia Ostrogska
EWELINA SUSZEK

ORCID: 0000-0002-6574-5842

Instytut Humanistyczny, Państwowa

Wyższa Szkoła Zawodowa w Tarnowie

\title{
Mizocz - palimpsest ${ }^{\star}$
}

\section{Podróż}

Po około dwóch godzinach jazdy samochodem od Lwowa na wschód należy być bardzo uważnym. Tablica kierunkowa na Mizocz (rejon zdołbunowski obwodu rówieńskiego zachodniej Ukrainy) jest słabo widoczna, a im dalej od drogi głównej, tym bardziej trasa staje się niekomfortowa. Wyboje są zdecydowanie większe, teren zaś prawie niezagospodarowany. Przez około pół godziny mija się niemal tylko stepy i przydrożne drzewa.

Ponieważ wkrótce zacznie zmierzchać, a wyprawa wydaje się nie mieć końca, zaczynamy wątpić w jej sensowność, zwłaszcza że została podjęta dość spontanicznie (wprawdzie myślałyśmy o niej już znacznie wcześniej, ale nie planowałyśmy jej na ten dzień). Zastanawiamy się, czy kiedy (jeśli?) dotrzemy na miejsce, cokolwiek zobaczymy. Jest obco. GPS nie działa. Nie ma się też kogo zapytać o drogę. W pewnym momencie zauważamy samotną, otoczoną małym sadem chatkę i pukamy do jej drzwi. Jej mieszkaniec - mówiący gwarą starszy pan - doradza, by wciąż kierować się prosto, a w Mizoczu łatwo wskażą nam „to miejsce” i z pewnością go nie przeoczymy. Czujemy ulgę, choć jeszcze nie spokój. Kiedy docieramy do miasteczka, nie mamy wątpliwości, że jesteśmy na prowincji. Wyczytany wcześniej w polskiej Wikipedii opis: „Mizocz - osiedle typu miejskiego", nijak się ma do naszych wrażeń, choć oczywiście zabudowa jest

* Badania terenowe prowadzone były w związku z udziałem w programie Erasmus+ realizowanym w ramach współpracy Uniwersytetu Śląskiego z Uniwersytetem Narodowym Akademią Ostrogską. Prowadzono je w roku akademickim 2017/2018. 
już gęstsza niż ta, którą mijałyśmy jakiś czas temu. Ponieważ musimy dotrzeć do centrum, wypatrujemy wyznaczającej je cerkwi. Zabytkowa cerkiew Narodzenia Najświętszej Marii Panny (dawny kościół pw. św. Jana Nepomucena) okazuje się dość ładna - biała, z kopułami (jedna niebieska, dwie złote), i jednocześnie bardzo typowa dla ukraińskiego krajobrazu. Ponieważ droga się rozgałęzia, a nie ma żadnych tablic, znów nie mamy pojęcia, gdzie jechać. Szczęśliwie w pobliżu znajduje się budynek przypominający z daleka dom chłopa/dom kultury. Sądząc po dobiegającej muzyce, odbywa się tam rodzinna uroczystość. Przed budynkiem stoją jej uczestnicy - kobieta w chuście i dwóch mężczyzn. Przyjęcie musi być mocno zakrapiane, więc żywo prowadzona narracja o tym, jak dojechać do naszego punktu docelowego, zdaje się nie kończyć podobnie jak podróż. Staramy się nie okazywać zniecierpliwienia, chociaż do zachodu słońca już bardzo blisko. Czas nam zdecydowanie nie sprzyja. Ponieważ to Wielki Poniedziałek, musimy uważać nie tylko na wyboje, ale także na lekko lub całkiem mocno zataczających się pieszych. Mijamy remizę strażacką, szereg zwykle ubogich, podniszczonych, przygnębiających zabudowań i jedziemy wciąż pod górę, aż droga przekształca się w polną. Zatrzymujemy się. Staruszek z chatki miał rację, przewidując, że nie przeoczymy.

\section{Na miejscu? Przesunięcia}

Dlaczego stale będąc niepewne trasy, wiedziałyśmy, gdzie jest jej cel? Po dawnym getcie żydowskim w Mizoczu nie pozostało zbyt wiele śladów ${ }^{1}$. Najważniejszym w pierwszym odbiorze znakiem tego, że coś się tu niegdyś wydarzyło,

\footnotetext{
${ }^{1}$ Szacuje się, że w obwodzie rówieńskim są 94 miejsca, w których doszło do mordu Żydów, ale zaledwie jedna czwarta z nich została oznakowana. Roman Mychalczuk (Роман Михальчук) badacz polityki pamięci - wskazuje na marginalizację tematyki Zagłady w ukraińskim środowisku akademickim, co przejawia się w przeświadczeniu, że zagadnienia te powinny być poruszane przez żydowskich badaczy, podczas gdy ukraińscy autorzy powinni zająć się np. Wielkim Głodem. Jego zdaniem dominuje postawa „obserwatora” (nie utrudniać, ale również nie pomagać), a to nie wzmacnia świadomości społecznej. O samym Mizoczu jako symbolu masowego mordu Żydów w Europie Wschodniej stało się jednak głośno m.in. za sprawą wystawy w muzeum Topographie des Terrors w Berlinie. Zob. Р. Михальчук: Пам'ять про Голокост у Мізочі: роздуми про українські та закордонні комеморативні практики [R. MүснALCZUк: „Pamięć о Holokauście w Mizoczu. Refleksje na temat ukraińskich i zagranicznych praktyk pamiątkowych"]. Dostępne w Internecie: http://uamoderna.com/event/mykhalchuk-memory-about-holocaust [data dostępu: 22.08.2017]; Tenże: Пам'яmь про Мізоцьку катастробу [„Рamięć о katastrofie w Mizoczu"]. Dostępne w Internecie: http://mnemonika.org.ua/wp-content/uploads/2016/12/ Myhalchuk_R.pdf [data dostępu: 22.08.2017]. Wszystkie przytoczone w przypisach ukraińskie tytuły przetłumaczyła Natalia Parfeniuk, korekty stylistycznej dokonała Ewelina Suszek.
} 
jest pomnik widoczny z daleka nie tylko ze względu na swój wyrazisty kształt i wysokość (około 6 metrów), ale też lokalizację na szczycie niedużego wzgórza. $\mathrm{Na}$ nim widnieje napis w języku ukraińskim: „Pamięci ofiar Holokaustu 1942 roku” („В пам’ять жертвам Голокосту 1942 року”), i płaskorzeźba przedsta-

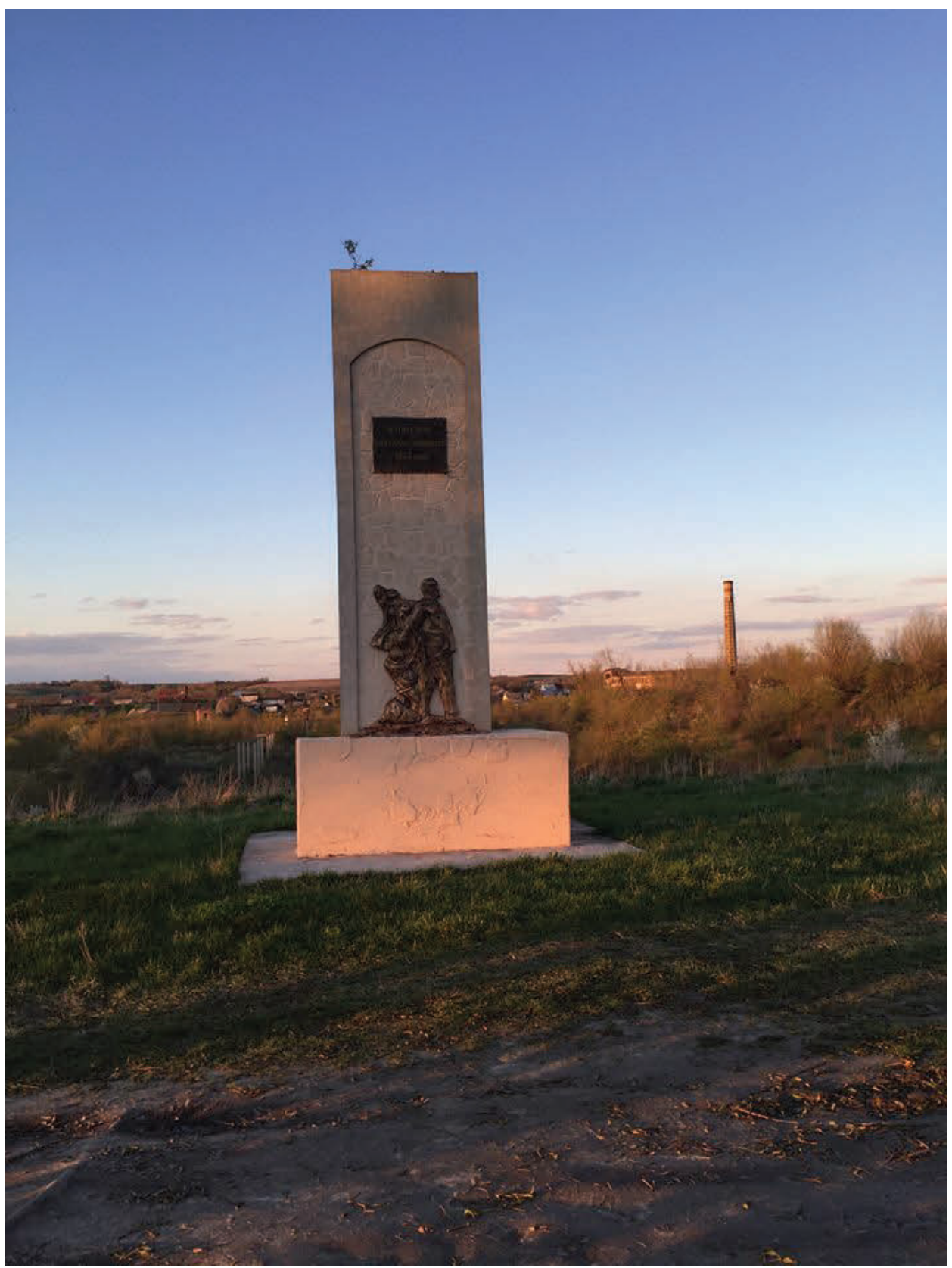

Fot. 1 


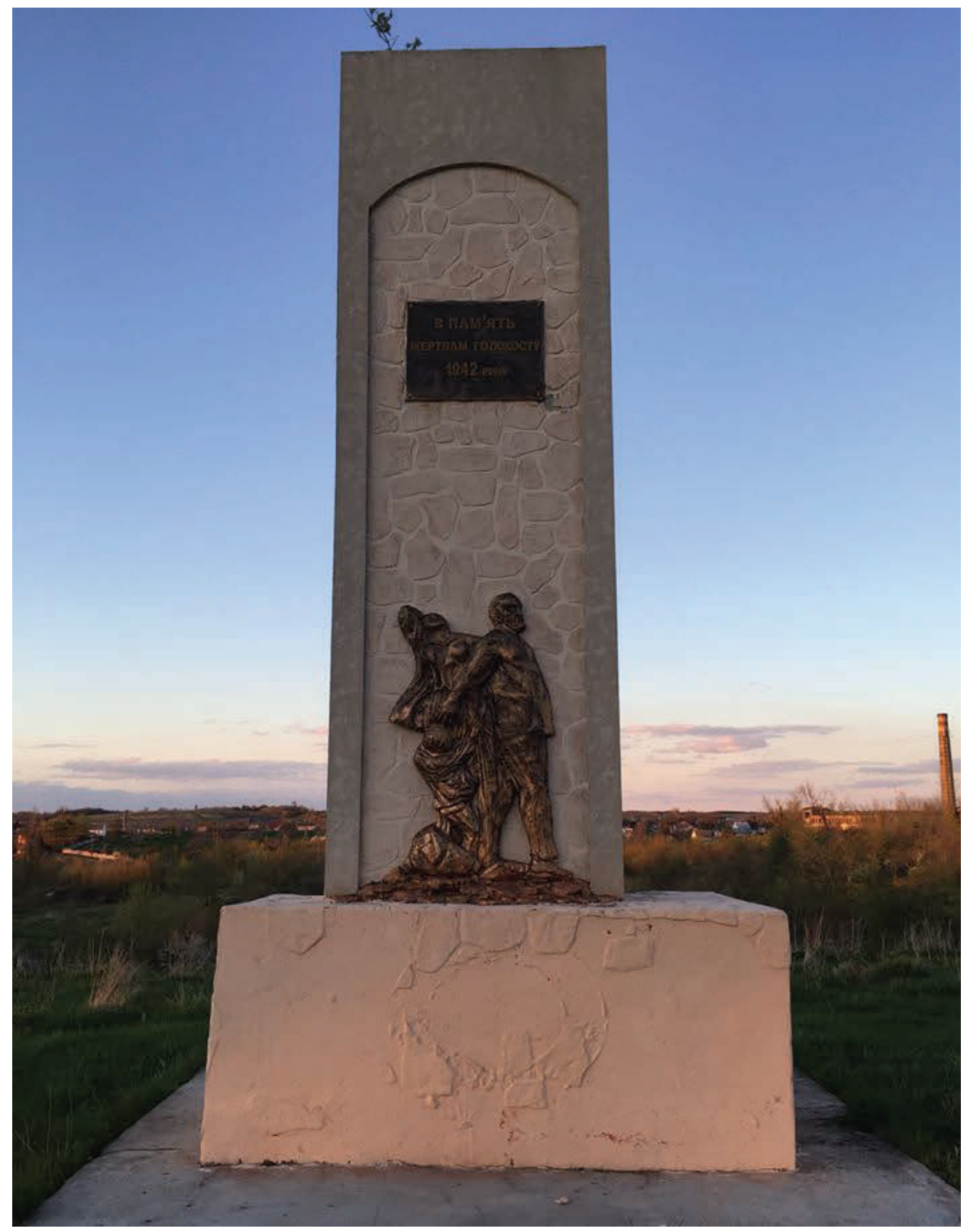

Fot. 2

wiająca trzy postacie (mężczyzna osłania kobietę z dzieckiem). Za obeliskiem jest łąka, teren nagle obniża się, ruiny czegoś (ponoć dawnej fabryki), jeszcze dalej widać mijane wcześniej domy i drzewa. Na pobliskich łąkach pasą się konie. Gdy zaczyna się ściemniać, przychodzi po nie gospodarz. Ciszę niespodziewanie przerywa stary, gruchoczący autobus z trudem jadący po nierównym terenie. 


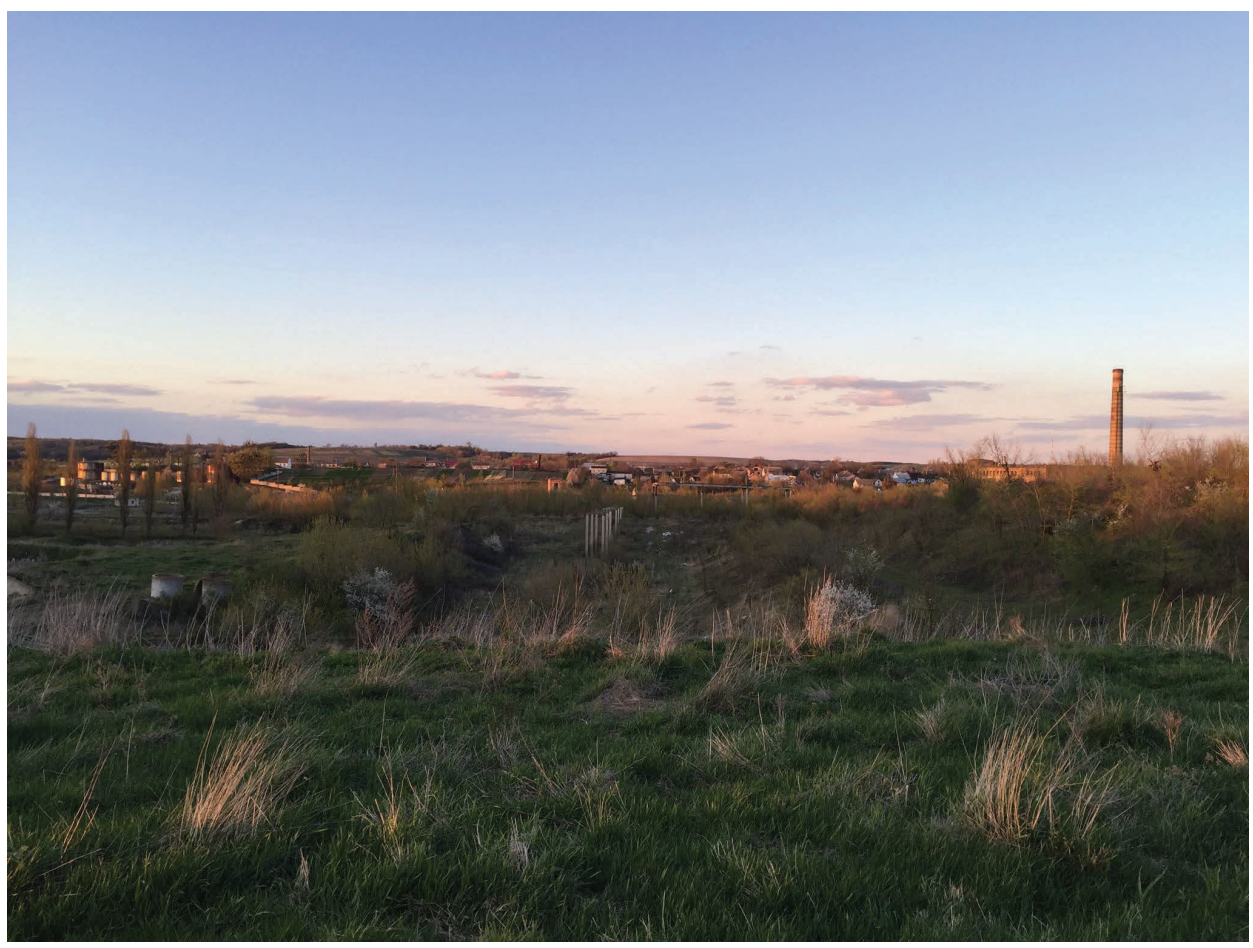

Fot. 3

Niektóre elementy krajobrazu (łąka z końmi o zachodzie słońca) pasowałyby do sielankowej scenerii. A jednak było tak, jak pisała Roma Sendyka: „Polana w lesie, kępa drzew, zarośnięty pagórek - mieszkańcom Europy Środkowo-Wschodniej miejsca te nie są obce, choć pozornie nie różnią się od otoczenia, jednak otacza je i wyróżnia coś niepokojącego”. "Coś jest nie tak”, „coś jest dziwnego, a nawet przerażającego" - rozmawiamy ze sobą, powtarzając słowa tych, którzy odwiedzają (prawie) zapomniane miejsca Zagłady ${ }^{3}$. Pastwiska Mizocza okazują się typowym "miejscem zdeformowanym”, ponieważ zakorzenione są jednocześnie w dwóch porządkach: „tu i teraz” oraz „tam i wtedy”. To, co widać gołym okiem i słychać (a właściwie częściej nie słychać), stanowi pierwszą warstwę palimpsestu ${ }^{5}$.

${ }^{2}$ R. Sendyka: Pryzma - zrozumieć nie-miejsce pamięci („non-lieux de memoire”). „Teksty Drugie" 2013, nr 1-2, s. 323.

${ }^{3}$ Zob. tamże; M. Toмczok: Postgraniczność gett w Będzinie i Sosnowcu a jej kulturowe reprezentacje. W: Monady. Polsko-niemiecko-żydowskie po(st)graniczne narracje miejskie. Red. A. GAlant, E. Krasucki, P. Krupiński i P. Wolski. Budapeszt-Kraków 2015, s. 309-311, 316-317.

${ }^{4}$ Zob. R. Sendyka: Pryzma..., s. 324.

${ }^{5}$ O „geo-palimpseście” oraz „osadowym charakterze” w odniesieniu do miejsc Zagłady pisze Roma Sendyka. Zob. tamże, s. 330. 
Nawet postawiony w 1989 roku, dziś zarastający od góry roślinnością monument ma „osadową" naturę. Pierwotnie umieszczony na nim napis był dłuższy od obecnego: „Wieczna pamięć ludności żydowskiego pochodzenia rozstrzelanej przez faszystów w 1942 roku” („Вічна пам’ять розстріляним фашистами людям єврейського походження у 1942 році”). Gipsowa płaskorzeźba również była inna - początkowo przedstawiała na pół obnażoną rodzinę żydowską (matka trzymała dziecko, a ojciec leżał ranny). Po renowacji w 2012 roku mężczyzna prezentuje się jako silny obrońca swych bliskich, stając się tym samym pierwszoplanową postacią ${ }^{7}$ To niejedyne „przesunięcie”. Pomnik stoi przy drodze, w odległości około 200-300 metrów od miejsca rozstrzelań.

Właściwe miejsce mordu - do dzisiaj nieogrodzone i zarośnięte trawą wskazali świadkowie wydarzeń (na przykład Vladimir Markovich Bidyuk) oraz zagraniczni badacze (prace prowadzone przez Institute for Visual History and Education Foundation USC Shoah w USA oraz Yahad-In Unum we Francji) ${ }^{8}$. W latach 50. ubiegłego wieku mieszkańcy miasteczka znajdywali na tym terenie ludzkie kości. A w związku z tym, że nie brakowało poszukiwaczy złota, władze sąsiadniego zakładu postarały się o kilkakrotne pokrycie obszaru dodatkową warstwą gleby ${ }^{9}$.

Ważnym dowodem w próbach określenia miejsca Zagłady są również zdjęcia wykonane w trakcie egzekucji (obecnie przechowywane w United States Holocaust Memorial Museum) ${ }^{10}$. Ich autor - prawdopodobnie Niemiec o nazwisku Gustav Gille - przyjął odgórną perspektywę. Fotografie prezentują niemieckich żołnierzy SS oraz ukraińskie oddziały policji w trakcie masowego mordu kobiet i dzieci. Widzimy, jak ofiary ustawiają się w szeregu na chwilę przed rozstrzelaniem, a także jak leżą już martwe lub są dobijane przez oprawców. W takim efemerycznym, ontologicznym zawieszeniu postacie ze zdjęć uchwyca Bracha Lichtenberg Ettinger ${ }^{11}$. Między innymi fotografie $z$ Mizocza stają się w jej pracach „materiałem wyjściowym”, na który nakłada się transparentne warstwy

${ }^{6}$ Zob. Мізоч. Містечко на Волині [„Mizocz. Miasteczko na Wołyniu”]. Dostępne w Internecie: http://kordonnij-prostir.martin-opitz-bibliothek.de/mizoch/ [data dostępu: 22.08.2017].

7 Zob. Р. Михальчук: Пам'ять про Мізоцьку катастрофу...

${ }^{8}$ Zob. Р. Михальчук: Пам'ять про Голокост у Мізочі: роздуми про украӥнські та закордонні комеморативні практики...

${ }^{9}$ Р. Михальчук: Пам'ять про Мізоцьку катастрофу...

${ }^{10}$ Zdjęcia można obejrzeć m.in. na oficjalnej stronie muzeum. Zob. http://digitalassets. ushmm.org/photoarchives/result.aspx?max_docs=1000\&search=Mizocz\&Submit=Search\&que ry_append= [data dostępu: 22.08.2017]. Na zdarzające się błędy w opisie tych fotografii zwraca uwagę Tomasz Stempowski. Zob. Tenże: Ostrożnie z podpisami. Dostępne w Internecie: http:// fototekst.pl/ostroznie-z-podpisami/ [data dostępu: 22.08.2017].

${ }^{11}$ Prace B.L. Ettinger prezentowane były na pierwszej w Polsce indywidualnej i przekrojowej wystawie artystki „Eurydyka - Pieta” w Muzeum Śląskim w dniach 8.07-2.09.2017 r. Można je również zobaczyć na stronie internetowej: http://bracha-ettinger.muzeumslaskie.pl/prace/ [data dostępu: 23.08.2017]. 
farb. Nie ma to być gest zacierania śladów, lecz zbliżania się do traumatycznych doświadczeń ${ }^{12}$. Jej głównymi bohaterkami - $\mathrm{w}$ przeciwieństwie do tego, co przedstawiono na wołyńskiej steli - są kobiety (matki) - współczesne Eurydyki.

Co jeszcze świadczy o przeszłości Mizocza? Zauważalny na zdjęciach i zachowany do dzisiaj rów oraz wspomniane ruiny fabryki. Można je uznać za swoiste pomniki upamiętniające Zagładę w podobny sposób, jak Frank Ankersmit czynił to w odniesieniu do budynków Auschwitz ${ }^{13}$. Co zatem upamiętniają? Czego niemymi świadkami były?

\section{Rów i nasypy}

27 czerwca 1941 roku wojska niemieckie wkroczyły do zamieszkiwanego przez Ukraińców, Polaków, Żydów i Czechów Mizocza. Wiadomość o tym została pozytywnie przyjęta przez obóz nacjonalistyczny. Ludność ukraińska patrzyła na żołnierzy jak na wyzwolicieli, początkowo nie odczuwając z ich strony względem siebie żadnej agresji. Tymczasem już 29 czerwca rozpoczęły się pogromy Żydów. Hitlerowcy narzucili im obowiązkową rejestrację, nakaz noszenia gwiazdy Dawida ${ }^{14}$, a także przymus pracy w cukrowni, której ruiny widziałyśmy, stojąc na wzniesieniu. Jesienią 1941 roku utworzono getto, gdzie umieszczono około 2 tysięcy Żydów z okolic ${ }^{15}$.

Jak wspominają ukraińscy świadkowie, do czasu, gdy Żydom pozwalano wychodzić do miasta, prosili oni o żywność swoich przyjaciół. Później w obliczu głodu, który zapanował w getcie, mieszkańcy Mizocza przerzucali im żywność przez ogrodzenie. Zwłaszcza dzieci w formie zabawy strzelały z procy małymi jabłkami lub orzechami, a łobuzerskie wybryki zwykle uchodziły bezkarnie.

12 Zob. A. Снromiк: Eurydyka i Pieta, ogień i woda, ratunek i ewakuacja: ślady traumy w twórczości Brachy L. Ettinger. Dostępne w Internecie: http://bracha-ettinger.muzeumslaskie.pl/ teksty/dr-anna-chromik/ [data dostępu: 23.08.2017].

${ }^{13}$ Zob. F. Ankersmit: Pamiętając Holokaust: żałoba i melancholia. Przeł. A. Ajschtet i in. W: F. Ankersmit: Narracja, reprezentacja, doświadczenie. Studia z teorii historiografii. Red. E. DomańsKa. Kraków 2004, s. 421-422.

${ }^{14}$ Zob. P. Михальчук: Трагедія мізоцьких євреїв [R. Mүснацсzuк: „Tragedia Żydów Mizocza"]. Dostępne w Internecie: http://jewish-museum-marmer.dp.ua/index.php?option=com_ content\&view=article\&id=156:2012-10-18-13-22-18\&catid=4:2011-06-02-03-36-17\&Itemid=5 [data dostępu: 14.11.2018]. O „propagandowych umizgach” żołnierzy Rzeszy względem Ukraińców zob. R.-D. MüLler: Wspólnicy Hitlera: formacje sojusznicze Wehrmachtu na froncie wschodnim. Przeł. J. Wolska-Stefanowicz. Warszawa 2010.

15 Zob. Encyclopedia of Camps and Ghettos, 1933-1945. Dostępne w Internecie: https://www. ushmm.org/research/publications/encyclopedia-camps-ghettos/volumes-i-and-ii-available-on line [data dostępu: 25.06.2018]. 
Bardziej spektakularnie, ale zgodnie z rozporządzeniem, Niemcy planowali obejść się z Terentijem Parfeniukiem, który nielegalnie dostarczał wołowinę. Schwytany wraz z dwoma żydowskimi pomocnikami miał zostać zabity na oczach mieszkańców miasteczka, ale błagania jego córki Niny uratowały go przed karą, której nie uniknęli jego wspólnicy ${ }^{16}$.

W nocy z 13 na 14 października 1942 roku faszyści rozpoczęli akcję likwidacji getta, wcześniej otoczonego kordonem. Żydzi, poinformowani o wywózce do pracy przymusowej w Rzeszy, dostali nakaz zbiórki o godzinie 16. Według ludowych podań na niebie miały się wówczas pokazać znaki zapowiadające przyszłą tragedię $e^{17}$. Ponieważ Żydzi z Mizocza - w przeciwieństwie do tych z miejscowości Równe - częściowo przynajmniej domyślali się prawdy, podczas marszu wrzucali kosztowności do okolicznej rzeki, by nie dostały się one w ręce Niemców. Stosunkowo wcześnie, bo już w trakcie wędrówki, rozpoczęły się pierwsze rozstrzelania. Na przodzie kolumny jechał na motocyklu gestapowiec Gille fotografujący wydarzenia. On też odpowiedzialny był za sprawny przebieg segregacji przedmiotów należących do Żydów. Stosy, na których oddzielnie składano odzież, obuwie i kosztowności, znajdowały się około 20 metrów od rowu. Rów o wymiarach 50 metrów długości, 7 - szerokości i 6 - głębokości nakazano wcześniej wykopać Żydom, rzekomo na potrzeby oddalonej o 300 metrów cukrowni. Nagie ofiary zapędzano do dołu i ustawiano je koło siebie, by w trakcie strzelania zaoszczędzić na amunicji. Zdarzało się, że niektórzy wciąż żyli podczas zakopywania. Liczba zabitych jest trudna do dokładnego określenia - waha się między 1700 a $4000^{18}$. Masowe morderstwa trwały sześć dni i podzielone zostały na kilka etapów ${ }^{19}$. W ich trakcie wybuchł w getcie pożar. Istnieje kilka wersji wyjaśniających jego przyczynę. Możliwe, że to Niemcy podpalili getto, by wypłoszyć z niego Żydów. Wiarygodne jest również, że uczynili to sami mieszkańcy, co odczytuje się albo jako ostatni przejaw oporu (samodzielny wybór śmierci, zniszczenie majątku, by nie dostał się w niepowołane ręce), albo jako próbę odwrócenia uwagi oprawców, mającą umożliwić ucieczkę. Szacuje się, że w ogniu zginęło około 200 osób, ale niektórym udało się wydostać na wolność. Utworzona $\mathrm{z}$ uciekinierów nędznie uzbrojona partyzantka została jednak w większości pojmana ${ }^{20}$.

Przeżyły zaledwie pojedyncze osoby. Do historii przeszło szczęśliwe ocalenie Zofii Gorsztein. Gdy rozpoczął się pogrom, nastoletnia dziewczyna uciekła

16 Zob. Р. Михальчук: Трагедія мізоцььких євреїв...; Мізоч. Містечко на Волині...

17 Zob. Р. Михальчук: Трагедія мізоцьких євреїв...

${ }_{18}$ Zob. tamże. Zob. Р. Михальчук: Пам'ять про Голокост у Мізочі: роздуми про украӥнські та закордонні комеморативні практики... Lista nazwisk zamordowanych znajduje się na stronie internetowej: http://www.jewishgen.org/yizkor/Mizoch/miz294.html [data dostępu: 24.08.2017].

19 Zob. Р. Михальчук: Трагедія мізоцьких євреїв...

${ }^{20}$ Zob. tamże. 
i ukryła się w domu koleżanki z klasy - Maryi Slobodiuk. Przebywała tam do lipca następnego roku, kiedy to naziści przeszukali chatę. I wówczas jednak Zofii nic się nie stało, ale dla bezpieczeństwa gospodarz skierował ją do swoich krewnych, u których mieszkała aż do końca okupacji niemieckiej.

Oleksij Slobodiuk (bratanek Maryi), pozostając pod wrażeniem rodzinnych opowieści, stworzył obraz I мертвим і живим синам Ізраілєвим в пам'ять про mрагедію Мізоча в 1942 pou̧i (I martwym i żywym synom Izraelu dla pamięci o tragedii Mizocza w 1942 roku $)^{21}$. Na malowidle widać wiele: kolumnę prowadzonych na śmierć Żydów, eksterminację, w oddali pożar getta i cukrownię, a na pierwszym planie rodzinę ratującą Zofię. Przy wiejskiej chacie rozgrywa się taka oto scena: najmłodszą siostrę Maryi, Raje, hitlerowiec kusi czekoladką, by zdradziła miejsce ukrywania Żydówki - dziewczynka jednak tego nie robi ${ }^{22}$.

Po wojnie Zofia wyjechała do Izraela, gdzie opowiedziała swoje losy w Jad Waszem. Ukraińska rodzina została odznaczona medalem „Sprawiedliwi wśród Narodów Świata”. W lipcu 1999 roku ocalała przyjechała na Wołyń, by spotkać się ze swoją przyjaciółką ${ }^{23}$. Zniesienie żelaznej kurtyny zmieniło nieco sposób prowadzenia ukraińskiej polityki pamięci (radziecka ideologia nakazywała oddawać cześć raczej weteranom, a nie ludności cywilnej) ${ }^{24}$. Ogrodzono pozostałości żydowskiego cmentarza w mieście. Lokalne władze z okazji siedemdziesiątej rocznicy tragedii odsłoniły odnowiony pomnik i uczciły poległych minutą ciszy. Począwszy od lat 90., do Mizocza przybywają zagraniczne delegacje, które sypią wokół pomnika izraelską ziemię. W ten sposób tworzy się kolejną warstwę palimpsestu.

${ }^{21}$ Zdjęcie obrazu namalowanego na płótnie o wymiarach 1,8 $\mathrm{m} \times$ 0,5 m można zobaczyć na stronie internetowej: http://kordonnij-prostir.martin-opitz-bibliothek.de/mizoch/ [data dostępu: 24.08.2017].

${ }^{22}$ Por. tamże.

${ }^{23}$ Zob. tamże.

${ }^{24}$ Zob. Р. Михальчук: Пам’ять про Мізоцьку катастрофу... 